\title{
PENGARUH PEMANFAATAN BOKASHI FESES SAPI TERHADAP PERTUMBUHAN SORGUM VARIETAS KAWALI
}

\author{
Susisusanty Imban, A. Rumambi*, S. S. Malalantang
}

\section{Fakultas Peternakan Universitas Sam Ratulangi Manado, 95115}

\begin{abstract}
ABSTRAK
Penelitian pengaruh pemanfaatan bokashi feses sapi terhadap pertumbuhan sorgum varietas kawali telah dilakukan. Tujuan penelitian adalah untuk mengetahui dan memperoleh data pengaruh pemanfaatan bokashi feses sapi menggunakan EM4 terhadap pertumbuhan sorgum varietas Kawali. Rancangan yang digunkan adalah Rancangan Acak Lengkap (RAL) yang terdiri dari 4 perlakuan dan 5 ulangan sehingga diperoleh 20 satuan percobaan. Perlakuan terdiri dari $\mathrm{P} 0=$ tanpa pemupukan, $\mathrm{P} 1=$ Pemupukan $4 \mathrm{~kg}, \mathrm{P} 2=$ Pemupukan $8 \mathrm{~kg}$, $\mathrm{P} 3=$ Pemupukan $12 \mathrm{~kg}$. Variabel yang diukur adalah tinggi tanaman, jumlah daun dan lebar daun. Hasil analisis statistik menunjukan bahwa perlakuan pemberian bokashi feses sapi $12 \mathrm{~kg} /$ petak memberikan pengaruh yang sangat nyata $(\mathrm{P}<0,01)$ terhadap tinggi tanaman, jumlah daun, dan lebar daun. Uji lanjut BNJ pada perlakuan tinggi tanaman menunjukan bahwa antara P3 dan P0, P3 dan P1, berbeda sangat nyata $(\mathrm{P}<0,01)$ akan tetapi antara P3 dan P2 menunjukan perbedaan tidak nyata $(\mathrm{P}>0,05)$. Pada perlakuan jumlah daun Uji lanjut BNJ menunjukan antara P3 dan P0 berbeda sangat nyata $(\mathrm{P}<0,01)$, akan tetapi antara $\mathrm{P} 3$ dan $\mathrm{P} 1, \mathrm{P} 3$ dan $\mathrm{P} 2$, menunjukan perbedaan yang tidak nyata $(\mathrm{P}>0,05)$. Pada perlakuan lebar daun juga uji lanjut BNJ menunjukan bahwa antara P3 dan P0 berbeda sangat nyata $(\mathrm{P}<0,01)$, akan tetapi antara $\mathrm{P} 3$ dan $\mathrm{P} 1, \mathrm{P} 3$ dan $\mathrm{P} 2$, menunjukan perbedaan yang tidak nyata $(\mathrm{P}>0,05)$. Berdasarkan hasil penelitian dapat disimpulkan bahwa pemberian pupuk bokashi feses sapi sampai
\end{abstract}

*Korespondensi (Corresponding author) Email : Agnitjerumambi@ymail.com dengan $12 \mathrm{~kg} /$ petak memberikan pengaruh yang terbaik terhadap tinggi tanaman, jumlah daun, dan lebar daun tanaman sorgum.

Kata kunci : Sorgum, Pertumbuhan, Feses sapi, EM4,

\section{ABSTRACT}

\section{UTILIZATION EFFECT OF CATTLE FECES BOKASHI ON GROWTH OF Kawali SORGHUM} VARIETY . The Research about effect of utilization cow manure on growth of sorghum variety kawali has done. The aim of this research is to obtain data and determine the effect of utilization cow manure mixed with EM4 on growth of sorghum variety kawali. This study was conducted using a completely randomized design (CRD) which consists of 4 treatments and 5 replicates in each treatment. The treatments were divided into plots of the experimental unit without fertilizer (P0), the plot using organic fertilizer of $4 \mathrm{~kg} / 6 \mathrm{~m}^{2}$ (P1), plot using organic fertilizer of $8 \mathrm{~kg} / 6 \mathrm{~m}^{2}(\mathrm{P} 2)$, and plot using organic fertilizer of $12 \mathrm{~kg} / 6 \mathrm{~m}^{2}$ (P3). The variables measured in this study were plant height, number of leaves and leaf width. The HSD test indicated that at high treatment plants showed that treatments between P3 and $\mathrm{P} 0$ and between P3 and P1 were highly significant. However, treatments between P3 and P2 showed no significant difference. In the treatments of advanced test HSD indicated also that number of leaves between P3 and P0 showed highly significant, but 
between $\mathrm{P} 3$ and $\mathrm{P} 1$, and between $\mathrm{P} 3$ and $\mathrm{P} 2$ showed no difference. In the treatment of wide leaves using HSD test showed that treatment between P3 and P0 was highly significant, but those between P3 and P1 and between P3 and P2 showed no difference. Statistical analysis showed that treatment using cattle feces bokashi as the organic fertilizer of $12 \mathrm{~kg} / 6 \mathrm{~m}^{2}(\mathrm{P} 3)$ produced high significant influence on plant height, leaf number, and leaf width. Based on this research it can be concluded that cattle feces bokashi as the organic fertilizer up to $12 \mathrm{~kg} /$ plot of $6 \mathrm{~m}^{2}$ produced the best effect on plant height, leaf number, and leaf width of kawali sorghum variety.

Key words: Sorgum, growt, Cattle feces bokashi,EM4.

\section{PENDAHULUAN}

Hijauan merupakan sumber pakan yang utama dan sangat besar peranannya bagi ternak ruminansia (sapi, kerbau, kambing dan domba) baik untuk hidup pokok, produksi maupun reproduksi. Kebutuhan hijauan semakin meningkat seiring dengan bertambahnya jumlah populasi ternak . Kendala utama di dalam penyediaan hijauan pakan baik kualitas maupun kuantitas secara berkesinambungan sulit tercapai hal ini dikarenakan pengembangan hijauan hanya memanfaatkan lahan kurang subur.

Sorgum (Sorgum bicolor L.Moench), merupakan salah satu jenis hijauan yang dapat di jadikan sumber pakan yang cukup potensial untuk dikembangkan di Indonesia karena sorgum memiliki keunggulan tahan terhadap kekeringan dibandingkan jenis tanaman serealia lainnya, mampu beradaptasi pada daerah yang luas, mulai dari daerah dengan iklim tropis-kering sampai daerah beriklim basah (Sumarno dan Karsono (1995). Ketahanan terhadap kekeringan disebabkan karena pada bagian batang dan daun terdapat adanya lapisan lilin, dimana daun dapat menggulung jika panas yang berlebihan sehingga mencegah penguapan atau transpirasi yang berlebihan. Sorgum memiliki kandungan nutrisi yang tinggi sehingga sangat baik di gunakan sebagai sumber bahan pakan alternatif.

Secara umum kualitas biji sorgum tidak berbeda jauh dengan jagung, sehingga pengembangan sorgum dalam bidang peternakan ditunjukkan untuk menggantikan sebagian atau seluruh peranan jagung dalam ransum ternak. Penggunaan biji sorgum dalam ransum ternak bersifat suplemen atau pengganti jagung. Bagian daun dan batang segar dapat dimanfaatkan sebagai pakan ternak.ruminansia. Kandungan nutrisi biji sorgum berdasarkan $100 \%$ bahan kering (BK) berupa Protein 10.26; Serat kasar 2.72; Lemak 2.70; Ca 0.90; dan P 0.38 (Rumambi, 2013), sedangkan produksi BK dan BO sorgum berturut-turut sebagai berikut 58,61 dan 58,65 (Koten $d k k$ 2012).

Dalam meningkatkan produktivitas sorgum diperlukan upaya peningkatan 
kesuburan tanah yaitu melalui penambahan unsur hara dengan memanfaatkan feses sapi dalam bentuk bokashi melalui fermentasi dengan pemberian EM4 (Effective Microorganisme-4). Pemupukan dapat menyediakan unsur hara yang diperlukan oleh tanaman dengan pemberian dosis yang tepat diharapkan dapat meningkatkan produktivitas tanaman sorgum. Bokashi merupakan salah satu jenis pupuk yang dapat menggantikan kehadiran pupuk kimia (anorganik) dalam manambah kesuburan tanah sekaligus memperbaiki kerusakan fisik, kimia, dan biologi tanah akibat pemakaian pupuk secara berlebihan. Bokashi merupakan hasil fermentasi bahan organik dari limbah pertanian (pupuk kandang, jerami, dan sekam serbuk gergaji dengan menggunakan EM-4 ( Gao et al, 2012 ; Atikah, 2013). EM-4 merupakan bakteri pengurai bahan organik yang memiliki keunggulan antara lain memperbaiki kondisi tanah, menekan pertumbuhan mikroba yang menimbulkan penyakit dan memperbaiki efisiensi penggunaan bahan organik oleh tanaman. Kelebihan bahan oganik bermanfaat dalam bidang peternakan, perikanan, dan pengelolahan limbah (Ruhukail, 2011).

Berdasarkan latar belakang diatas maka telah dilakukan penelitian tentang pengaruh pemanfaatan bokashi feses sapi menggunakan EM4 terhadap pertumbuhan sorgum varietas kawali.

\section{MATERI DAN METODE PENELITIAN}

\section{Tempat dan Waktu Penelitian}

Penelitian ini telah dilakukan di Desa Wusa Kecamatan Talawaan Minut, Rancangan yang digunakan adalah Rancangan Acak Lengkap (RAL menurut Steel dan Torrie, 1995) yang terdiri 4 perlakua dan 5 ulangan sehingga diperoleh 20 satuan percobaan. Petak digunakan berukuran $2 \times 3$ meter, jumlah tanaman perpetak adalah 18 tanaman dengan jarak tanam $50 \times 75 \mathrm{~cm}$. Perlakuan yang diberikan adalah :

$$
\begin{aligned}
& \text { P0 }=\text { Tanpa Pemupukan } \\
& \text { P1 }=\text { Pupuk Bokashi } 4 \mathrm{~kg} \\
& \text { P2 }=\text { Pupuk Bokashi } 8 \mathrm{~kg} \\
& \text { P3 }=\text { Pupuk Bokashi } 12 \mathrm{~kg}
\end{aligned}
$$

Peubah yang diukur dalam penelitian ini adalah :

- Tinggi tanaman (cm),

- Jumlah daun (helai) dan

- Lebar daun $(\mathrm{cm})$.

Bahan yang digunakan adalah : Benih sorgum variates kawali, feses sapi, EM4, gula putih, air sumur, serbuk gergaji, dedak halus dan tanah sebagai media tanam. Alat yang digunakan adalah sebagai berikut : Cangkul, meter, timbangan, parang, kamera, bambu, paku, kertas HVS warna, tali, plastik, gunting, 
gelas ukur, kamera, sekop, ember, terpal, termometer dan alat tulis menulis.

\section{Pembuatan Bokashi Feses Sapi}

Persiapan bahan berupa larutan EM4 + gula + air dicampur merata. Selanjutnya penyiapan bahan-bahan pengisi seperti feses sapi, dedak halus, sekam padi, serbuk gergaji, semua bahan pengisi di campur secara bertahap. Bahan olahan ditutup menggunakan karung goni. Pengecekan suhu dilakukan setiap 5-6 jam, apabila terjadi peningkatan suhu pada bahan olahan perlu dilakukan pembongkaran dengan cara membolakbalikan bahan tersebut agar terjadi penurunan suhu kemudian ditutup kembali. Bokashi dapat digunakan apabila telah memiliki ciri berwarna coklat kehitaman, tekstur lembut, gembur, tidak panas, dan tidak berbau.

\section{Persiapan lahan meliputi}

Pembersihan tanah dengan cara pembajakkan atau pembongkaran tanah kemudian dilakukan penyisiran agar bersih dari sisa-sisa tanaman dan rumput liar dilanjutkan dengan pembuatan petak sebanyak 20 petak dengan ukuran 2 x 3 meter, jarak antar petak adalah $50 \times 75$ $\mathrm{cm}$. Tanah yang telah dibuat petak-petak tadi dibiarkan selama 1 minggu untuk membiarkan kesempatan bagi rumput liar tumbuh kemudian dicangkul kembali. Sekaligus dengan pemberian pupuk sesuai perlakuan pada tiap-tiap petak.

\section{Penanaman}

Penanaman dilakukan dengan cara tunggal, dimana setiap lubang ditanami 23 butir, setelah tanaman berumur 1 minggu dilakukan penjarangan dengan meninggalkan satu tanaman per lubang. Setiap petak ditanami 18 tanaman sehingga keseluruhan petak berjumlah 360 tanaman.

Pemeliharaan tanaman meliputi penyiangan dilakukan apabila muncul tanaman pengganggu dalam petak percobaan. Penyemprotan dilakukan menggunakan furadan dan sefin pada tanaman yang terserang hama.

\section{Pengambilan data}

Pengambilan data dilakukan 2 minggu setelah tanaman berumur 2 minggu terhadap tinggi tanaman, jumlah daun, dan lebar daun.

\section{HASIL DAN PEMBAHASAN}

\section{Perlakuan Pemupukan Bokasi Feses Sapi Terhadap Tinggi Tanaman.}

Pengaruh perlakuan terhadap tinggi tanaman dapat dilihat pada tabel 1. Rataan tinggi tanaman tertinggi terdapat pada perlakuan P3 $(168,20 \mathrm{~cm})$ diikuti oleh P2 $(164,20 \mathrm{~cm})$, P1 $(151,80 \mathrm{~cm})$ dan yang terendah pada perlakuan P0 $(139,20 \mathrm{~cm})$. 
Tabel 1. Rataan Pengaruh Perlakuan Pemupukan Bokasi Feses Sapi Terhadap Tinggi Tanaman $(\mathrm{cm})$

\begin{tabular}{ccccc}
\hline \multirow{2}{*}{ Ulangan } & \multicolumn{4}{c}{ Perlakuan } \\
\cline { 2 - 5 } & $\mathrm{P} 0$ & $\mathrm{P} 1$ & $\mathrm{P} 2$ & $\mathrm{P} 3$ \\
\hline U1 & $\mathbf{1 4 5 . 0 0}$ & $\mathbf{1 5 3 . 0 0}$ & $\mathbf{1 7 0 . 0 0}$ & $\mathbf{1 6 7 . 0 0}$ \\
U2 & $\mathbf{1 4 8 . 0 0}$ & $\mathbf{1 5 2 . 0 0}$ & $\mathbf{1 6 6 . 0 0}$ & $\mathbf{1 7 5 . 0 0}$ \\
U3 & $\mathbf{1 4 0 . 0 0}$ & $\mathbf{1 5 0 . 0 0}$ & $\mathbf{1 6 7 . 0 0}$ & $\mathbf{1 7 1 . 0 0}$ \\
U4 & $\mathbf{1 2 8 . 0 0}$ & $\mathbf{1 4 5 . 0 0}$ & $\mathbf{1 6 1 . 0 0}$ & $\mathbf{1 6 7 . 0 0}$ \\
U5 & $\mathbf{1 3 5 . 0 0}$ & $\mathbf{1 5 9 . 0 0}$ & $\mathbf{1 5 7 . 0 0}$ & $\mathbf{1 6 1 . 0 0}$ \\
Rataan & $139.20 \pm 7,98^{\mathrm{a}}$ & $151.80 \pm 5,07^{\mathrm{b}}$ & $164.20 \pm 5,17^{\mathrm{c}}$ & $168.20 \pm 5,22^{\mathrm{c}}$ \\
\hline
\end{tabular}

Ket: Superscript yang berbeda pada baris yang sama menunjukan perbedaan

Hasil analisis sidik ragam menunjukan bahwa perlakuan pemupukan memberikan pengaruh yang sangat nyata $(\mathrm{P}<0,01)$ terhadap tinggi tanaman. Uji lanjut BNJ memperlihatkan bahwa perlakuan P3 menunjukan perbedaan yang lebih tinggi 20,833\% dibandingkan dengan P0 (kontrol/tanpa pemupukan). Selanjutnya pengaruh antara P3 dan P1 memberikan pengaruh yang nyata $(\mathrm{P}<0,01)$, sedangkan pengaruh perlakuan P3 dan P2 memberikan pengaruh yang berbeda tidak nyata $(\mathrm{P}>0,05)$ terhadap tinggi tanaman. Semakin tinggi level pupuk semakin tinggi pertumbuhan tanaman. Hal ini disebabkan karena pupuk bokashi feses sapi mengandung unsur hara makro dan mikro yang lengkap seperti N, P dan K, dimana bokashi tersebut memiliki kandungan hara yang meliputi: $3,22 \% \quad$ Nitrogen; $4,47 \%$ $\mathrm{K} 2 \mathrm{O}$; dan 3,24\% P2O5 (Syamsuddin dan Faesal, 2003). Unsur hara N berperan untuk merangsang pertumbuhan tanaman khususnya pada cabang, batang dan daun (Setiawan, 1998).

\section{Perlakuan Pemupukan Bokasi Feses} Sapi Terhadap Jumlah Daun.

Pengaruh perlakuan terhadap jumlah daun dapat dilihat pada tabel 2. Nilai rataan perlakuan P3 memberikan jumlah daun tertinggi yaitu 10,82 helai diikuti dengan perlakuan P2 (10,48 helai), P1(10,28 helai) dan yang terendah yaitu pada perlakuan P0 9,40 helai. 
Tabel 2 Rataan Pengaruh Perlakuan Pemupukan Bokasi Feses Sapi Terhadap jumlah daun.

\begin{tabular}{ccccc}
\hline & \multicolumn{5}{c}{ Jumlah Daun } \\
\cline { 2 - 5 } Perlakuan & P0 & P1 & P2 & P3 \\
\cline { 2 - 5 } U1 & $\mathbf{8 . 4 2}$ & $\mathbf{9 . 7 1}$ & $\mathbf{1 0 . 2 8}$ & $\mathbf{1 1 . 4 2}$ \\
U2 & $\mathbf{9 . 1 4}$ & $\mathbf{1 0 . 2 8}$ & $\mathbf{1 0 . 5 7}$ & $\mathbf{1 0 . 5 7}$ \\
U3 & $\mathbf{9 . 5 7}$ & $\mathbf{1 0 . 5 7}$ & $\mathbf{1 0 . 7 2}$ & $\mathbf{1 0 . 4 2}$ \\
U4 & $\mathbf{9 . 5 7}$ & $\mathbf{1 0 . 5 7}$ & $\mathbf{1 0 . 1 4}$ & $\mathbf{1 0 . 7 1}$ \\
U5 & $\mathbf{1 0 . 2 8}$ & $\mathbf{1 0 . 2 8}$ & $\mathbf{1 0 . 4 2}$ & $\mathbf{1 1}$ \\
Rataan & $9.40 \pm 0,68^{\mathrm{a}}$ & $10.28 \pm 0,35^{\mathrm{b}}$ & $10.43 \pm 0,23^{\mathrm{b}}$ & $10.82 \pm 0,40^{\mathrm{b}}$ \\
\hline
\end{tabular}

Ket: Superscript yang berbeda pada baris yang sama menunjukan perbedaan

$\begin{array}{rccr}\text { Hasil } & \text { analisis } & \text { sidik } & \text { ragam } \\ \text { menunjukan } & \text { bahwa } & \text { perlakuan } & \text { P3 } \\ \text { memberikan } & \text { pengaruh } & \text { berbeda } & \text { nyata }\end{array}$
$(\mathrm{P}<0,01)$ terhadap jumlah daun tanaman sorgum. Uji lanjut BNJ menujukan bahwa perlakuan $\mathrm{P} 3$ berbeda sangat nyata $(\mathrm{P}<0,01)$ lebih tinggi $15,10 \%$ dibandingkan dengan P0. Selanjutnya pengaruh perlakuan antara P3 dan P1, P3 dan P2 memberikan pengaruh berbeda tidak nyata $(\mathrm{P}<0,05)$. Jumlah daun terbanyak pada perlakuan P3 diduga disebabkan oleh ketersediaan unsur hara yang lebih banyak pada perlakuan P3 dimana bokashi feses sapi memiliki kandungan hara makro yang lengkap terutama Nitrogen. Pertumbuhan jumlah daun berkaitan dengan peran $\mathrm{N}$ sebagai komponen klorofil, bertambahnya $\mathrm{N}$ dalam tanah berasosiasi dengan pembentukan klorofil didaun sehingga meningkatkan proses fotosintesis yang memacu pertambahan jumlah daun tanaman. (Kusuma, 2013). Kandungan hara N dalam bokashi feses sapi sebesar 3,22 \% (Syamsuddin dan Faesal, 2003). Kandungan unsur hara K sekitar 4,47 $\%$ yang berpengaruh dalam proses pembentukan daun, dimana tanaman sangat membutuhkan unsur hara kalium dalam pembentukan karbohidrat sehingga menghasilkan jumlah daun yang banyak (Sucipto, 2010). Hasil penelitian ini hampir sama dengan hasil penelitian dari Hariadi (2015) yang menggunakan kombinasi pupuk kandang dan Tricho-kompos memperoleh jumlah daun yaitu 9,8311,69 helai. 
Tabel 3 Rataan Pengaruh Perlakuan Pemupukan Bokasi Feses Sapi Terhadap lebar daun.

\begin{tabular}{ccccc}
\hline \multirow{2}{*}{ Perlakuan } & \multicolumn{4}{c}{ Lebar Daun } \\
\cline { 2 - 5 } U1 & P0 & P1 & P2 & P3 \\
U2 & $\mathbf{6 . 8 5}$ & $\mathbf{8 . 8 5}$ & $\mathbf{8 . 9 2}$ & $\mathbf{9 . 1 4}$ \\
U3 & $\mathbf{8 . 2 1}$ & $\mathbf{9 . 0 7}$ & $\mathbf{8 . 2 8}$ & $\mathbf{8 . 9 2}$ \\
U4 & $\mathbf{7 . 7 1}$ & $\mathbf{8 . 3 5}$ & $\mathbf{9 . 0 7}$ & $\mathbf{9 . 2 1}$ \\
U5 & $\mathbf{7 . 7 8}$ & $\mathbf{8 . 2 8}$ & $\mathbf{9}$ & $\mathbf{9 . 3 5}$ \\
Rataan & $\mathbf{8 . 3 6}$ & $\mathbf{9}$ & $\mathbf{8 . 9 2}$ & $\mathbf{9 . 7 1}$ \\
\hline
\end{tabular}

Ket: Superscript yang berbeda pada baris yang sama menunjukan perbedaan

Perlakuan Pemupukan Bokashi Feses Sapi Terhadap Lebar Daun.

Pengaruh perlakuan terhadap lebar daun dapat dilihat pada Tabel 3. Pada tabel 3 dapat dilihat bahwa nilai rataan lebar daun yang terbaik diperoleh pada perlakuan P3, diikuti P2, P1 dan terendah P0 (kontrol).

Hasil analisis sidik ragam menunjukan bahwa perlakuan memberikan pengaruh yang berbeda sangat nyata $(\mathrm{P}<0,01)$ terhadap lebar daun. Uji Lanjut BNJ menunjukan bahwa perlakuan P3 berbeda sangat nyata $(\mathrm{P}<0,01)$ lebih tinggi $19,15 \%$ dibandingkan perlakuan P0 (kontrol). Selanjutnya pengaruh perlakuan antara P3 dan P1, P3 dan P2 menunjukan pengaruh yang berbeda tidak nyata $(\mathrm{P}<0,05)$. Hal ini diduga karena peranan EM4 dalam bokashi feses sapi berfungsi mempercepat proses dekomposisi bahan organik secara cepat dan berfungsi mengikat nitrogen dari udara dimana unsur hara $\mathrm{N}$ dapat berfungsi sebagai perangsang pertumbuhan tanaman secara menyeluruh terutama untuk pelebaran daun.

\section{KESIMPULAN}

Berdasarkan hasil penelitian yang telah dilaksanakan dapat disimpulkan bahwa pemberian pupuk feses sapi sampai dengan $12 \mathrm{~kg} /$ petak memberikan pengaruh yang terbaik terhadap tinggi tanaman, jumlah daun, dan lebar daun tanaman sorgum.

\section{SARAN}

Berdasarkan kesimpulan diatas maka disarankan penelitian ini dapat dilanjutkan dengan pemberian dosis pupuk feses sapi lebih dari $12 \mathrm{~kg} /$ petak. 


\section{DAFTAR PUSTAKA}

Atikah, T.A. 2013. Pertumbuhan dan hasil tanaman terung ungu varietas Yumi F1 dengan pemberian berbagai bahan organik dan lama inkubasi pada tanah berpasir. Anterior Jurnal Vol 12 (2):6-12.

Gao. M., Li J and X . Zhang 2012. Responses of soil fauna structure and leaf litter decomposition to effective microorganism treatments in dahinggan mountains, china. Chinese Geographical Science Vol 22(6):647-658.

Dewanto F.G., J.J.M.R. Londok. R.A.V Tuturoong. 2013. Pengaruh pemupukan anorganik dan organik terhadap produksi tanaman jagung sebagai sumber pakan. Jurnal Zootek. Vol.32 (5):1-8

Kusuma, M.E, 2003. Pengaruh pemberian bokhasi terhadap pertumbuhan vegetatif dan produksi rumput gajah (Pennicetum purpureum). Jurnal Ilmu Hewan Tropika Vol (2): 40-45.

Koten. B.B., Soetrisno R.Dj. Suwignyo. B. 2012. Produksi tanaman sorgum (Shorgum bicolor $L$. Moench) varietas lokal rote sebagai hijauan pakan ruminansia pada umur panen dan dosis pupuk urea yang berbeda. Buletin Peternakan Vol 36 (3) : 150-155.

Rumambi, A. 2013. Karakteristik pertumbuhan sorgum dengan pemupukan urea berbeda sebagai sumber nitrogen. Jurnal Agrosistem Vol 10 (1) : 1-12 .

Ruhukail N. L. 2011. Pengaruh penggunaan EM-4 yang dikulturkan pada bokashi dan pupuk anorganik terhadap produksi tanaman kacang tanah (Arachis hypogaea L) di kampung Wanggar Kabupaten Nabire. Jurnal Agroforestri Vol 4 (2):114-120.

Setiawan. A. I. 1998. Memanfaatkan Kotoran Ternak. Penebar Swadaya. Jakarta.

Sucipto. 2010. Efisiensi cara pemupukan terhadap pertumbuhan dan hasil beberapa varietas sorgum manis ( Sorgum bicolor L.Moench). Jurnal Embryo Vol 7 (2) : 67-74.

Sumarno dan S. Karsono. 1995. Perkembangan Produksi Sorgum di dunia dan Penggunaannya.

Steel, R.G.D dan J.H. Torrie 1995 Prinsip dan Prosedur Statistika. Gramedia, Pustaka Utama, Jakarta.

Syamsuddin dan Faesal. 2003. Pengaruh berbagai takaran bokashi terhadap hasil tanaman jagung. Jurnal Stigma. Vol 11(4):345-347. 